\title{
ANALISIS EKSPRESI TRANSPORTER ZINK (ZNT-1) SEBAGAI FAKTOR PROGNOSIS ADENOKARSINOMA PROSTAT
}

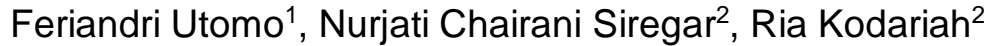

\begin{abstract}
Abstrak
Penurunan kadar Zink (Zn) berkorelasi dengan peningkatan skor Gleason adenokarsinoma prostat, dan rendahnya Caspase-3 (eksekutor apoptosis). Ekspresi ZIP-1 (importer Zn) turun pada adenokarsinoma prostat. Korelasi ZnT-1 (eksporter Zn), ZIP-1 dan Caspase-3 diduga berpotensi menjadi faktor prognosis adenokarsinoma prostat. Penelitian ini bertujuan menganalisis korelasi ekspresi ZnT-1, ZIP-1, Caspase-3 dan skor Gleason adenokarsinoma prostat. Studi retrospektif analitik potong lintang dilakukan pada 14 kasus adenokarsinoma prostat skor Gleason $\leq 7$ dan 16 kasus dengan skor Gleason $>7$. Ekspresi ZnT-1 dinilai dengan metode imunohistokimia. Analisis tambahan dilakukan untuk melihat korelasi ZnT-1, ZIP-1 dan Caspase-3. Hasil penelitian didapatkan ZnT-1 pada skor Gleason $>7$ lebih rendah daripada skor Gleason $\leq 7$. ZnT-1 berkorelasi dengan skor Gleason. ZnT-1 berkorelasi dengan ZIP-1 pada skor Gleason >7. ZIP-1 berkorelasi dengan Caspase-3 pada skor Gleason $\leq 7$. ZIP-1 berkorelasi kuat dengan Caspase-3 pada skor Gleason 8. Penelitian ini menyimpulkan rendahnya ekspresi ZnT-1 dan ZIP-1 berpotensi menjadi faktor prognosis adenokarsinoma prostat.
\end{abstract}

Kata kunci: ZnT-1, ZIP-1, Caspase-3, adenokarsinoma prostat, skor Gleason

\begin{abstract}
Low of Zinc (Zn) correlates with an increase of Gleason score grade of prostate adenocarcinoma and decrease of Caspase-3 (apoptosis executor). ZIP-1 (Zn importer) expression decrease in prostate adenocarcinoma. Correlation of ZnT-1 (Zn exporter), ZIP-1, and Caspase-3 allegedly potential to be prognostic factor of prostate adenocarcinoma. This study was aim to analyze the correlation of ZIP-1, ZnT1. Caspase-3 and Gleason score of prostate adenocarcinoma. A cross-sectional retrospective study analytic was conducted to adenocarcinoma Gleason scored $\leq 7$ (14 cases) and Gleason scored >7 (16 cases). ZnT-1 expression was seen using immunohistochemical staining. Additional analyzes were performed to examine the correlations between ZnT-1, ZIP-1 and Caspase-3. ZnT-1 in prostate adenocarcinoma with Gleason score $>7$ was lower than that of cases with Gleason score $\leq 7$. ZnT-1 correlated with gleason score. ZnT-1 correlated with ZIP-1 in the Gleason score >7. ZIP-1 correlated with Caspase-3 in the Gleason score $\leq 7$. ZIP-1 correlated with Caspase-3 in the Gleason score 8. In conclusion, low of ZnT-1 and ZIP-1 has the potential to be a prognostic factor of prostate adenocarcinoma.
\end{abstract}

Keywords: ZnT-1, ZIP-1, Caspase-3, prostate adenocarcinoma, Gleason score

Afiliasi Penulis: 1. Faculty of Medicine and Health Science Abdurrab University 2. Department of Pathology, Faculty of Medicine Univesity of Indonesia Korespondensi: Feriandri Utomo, email: feriandri.utomo@gmail.com, Telp/HP: 082169874330 


\section{PENDAHULUAN}

Kanker prostat termasuk lima kanker dengan jumlah penderita tertinggi pada lakilaki di Indonesia, yaitu berada pada urutan ke 5 dengan tingkat mortalitas $6,2 \%$ pada tahun 2008 dan naik menjadi urutan ke 3 dengan tingkat mortalitas $8,9 \%$ pada tahun 2012. ${ }^{1,2}$ Fakta perburukan tersebut semestinya menjadikan penelitianpenelitian terkait kanker prostat semakin banyak dilakukan. Jenis kanker prostat yang tersering terjadi adalah adenokarsinoma dengan karakteristik berupa keganasan kelenjar prostat. ${ }^{3}$

Zink (Zn) dapat berperan pada onkogenesis kanker prostat. Kadar Zn yang tinggi merupakan karakteristik dari sel prostat normal. ${ }^{4,5}$ Prostat mengandung kadar Zn tertinggi di tubuh manusia yaitu 3 kali lebih besar daripada jaringan lain. ${ }^{4,5}$ Kadar Zn yang rendah pada sel prostat memiliki efek secara metabolik dan pertumbuhan. ${ }^{4}$ Rendahnya kadar $\mathrm{Zn}$ akan menyebabkan terjadinya proses $m$ aconitase. ${ }^{4,5}$ M-aconitase merupakan proses oksidasi citrate menjadi iso citrate yang kemudian menjalani daur Krebs untuk menghasilkan energi berupa ATP. ${ }^{4,5}$ Keadaan tersebut menyebabkan sel-sel kanker prostat tercukupi kebutuhan energinya untuk berproliferasi. ${ }^{4}$ Selain itu, rendahnya kadar Zn juga berefek pada hilangnya efek pro apoptosis. ${ }^{4}$ Peningkatan produksi energi dan hilangnya proses apoptosis mengakibatkan peningkatan proliferasi sel kanker prostat. ${ }^{4}$

Keseimbangan kadar Zn sangat diatur oleh transporter $\mathrm{Zn}$ yang terdapat pada sitoplasma dan membran sel. ${ }^{4}$ Transporter Zn utama terdiri atas ZIP (SLC39) dan ZnT
(SLC30). ${ }^{4}$ ZIP berfungsi untuk meningkatkan kadar Zn pada sitoplasma dengan mengambil $\mathrm{Zn}$ dari cairan ektraseluler dan vesikel intraseluler. ${ }^{4}$ Fungsi ZIP yang meningkatkan kadar Zn, berperan dalam pengaturan apoptosis dengan menginduksi Bax yang bersifat proapoptosis. ${ }^{4}$ Peran tersebut terutama dilakukan oleh ZIP-1 yang rendah atau tidak diekspresikan pada kanker prostat. ${ }^{6}$ Keseimbangan kadar Zn juga diatur oleh ZnT yang berfungsi untuk mengeluarkan (efflux) Zn dari sel dan memasukkan $\mathrm{Zn}$ ke dalam organel intraseluler. ${ }^{4,5}$

Caspase-3 merupakan eksekutor utama terjadinya apoptosis yang menyebabkan fragmentasi DNA dan perubahan morfologi sel yang akan mengalami apoptosis. ${ }^{7}$ Adanya Caspase-3 aktif pada sel yang akan mengalami apoptosis adalah proses awal terjadinya apoptosis, sebelum terjadinya perubahan morfologi sel tersebut. ${ }^{7}$ Pada saat Caspase-3 aktif, sel pasti akan mengalami apoptosis dan tidak dapat kembali lagi menjadi sel normal. ${ }^{7} \quad$ Penentuan kuantitas imunoekspresi Caspase-3 merupakan metode yang tepat untuk mengukur aktivitas apoptosis kanker prostat. ${ }^{8}$

Penurunan kadar Zn pada prostat berkorelasi dengan peningkatan derajat skor Gleason adenokarsinoma prostat yang berkaitan dengan tingginya agresivitas. ${ }^{4}$ Keseimbangan kadar Zn diatur oleh ZIP dan $\mathrm{ZnT}$, sehingga perlu untuk diketahui bagaimana hubungan ZIP dan ZnT dalam karsinogenesis prostat. Penelitian Septiawan et $a l^{9}$ secara imunohistokimia, menemukan ekspresi ZIP-1 berkorelasi positif dengan Caspase-3 pada adenokarsinoma prostat skor Gleason <8. Peran ZnT-1 dalam proses 
karsinogenesis kanker prostat masih belum banyak diteliti. Hasumi et $a l^{10}$ menemukan terjadinya penurunan jumlah mRNA ZnT-1 pada jaringan kanker prostat yang dibandingkan dengan jaringan $\mathrm{BPH}$, sedangkan Beck et al dan Freeman et al (dikutip dari Franz et $a l^{4}$ ) tidak menemukan perbedaan bermakna jumlah mRNA ZnT-1 pada jaringan kanker prostat yang dibandingkan dengan Beningn Prostatic Hyperplasia (BPH). Penelitian lain yang dilakukan Beck et $a l^{4}$ dengan metode RT PCR mendapatkan ekspresi mRNA ZnT-1 pada BPH tidak berbeda bermakna dibandingkan dengan prostat normal, tetapi menurun pada jaringan kanker prostat. Winter et $a l^{11}$ dan Santamaria et $a l^{8}$ membuktikan bahwa terjadi penurunan ekspresi Caspase-3 pada jaringan kanker prostat dibandingkan dengan prostat normal.

Penelitian ini diharapkan dapat memperjelas peran ZnT-1 dalam karsinogenesis prostat, sehingga menjadi data dasar bagi penelitian selanjutnya di masa depan tentang potensi transporter $\mathrm{Zn}$ sebagai faktor prognosis adenokarsinoma prostat.

\section{METODE}

Desain penelitian ini adalah studi retrospektif dengan analitik potong lintang. Subyek penelitian ini merupakan 31 sediaan blok parafin prostat hasil prostatektomi yang telah didiagnosis lengkap dengan derajat skor Gleason oleh dokter spesialis patologi anatomi di Departemen Patologi Anatomik Fakultas Kedokteran Universitas Indonesia (FKUI) dari Januari 2006 hingga Desember 2013. Sesuai dengan kriteria inklusi dan eksklusi sampel penelitian ini, dipilih 30 kasus adenokarsinoma prostat yang 29 kasus di antaranya sama dengan penelitian Septiawan et $a l^{9}$ dan 1 kasus BPH. Sampel penelitian dikelompokkan menjadi BPH sejumlah 1 sampel, adenokarsinoma prostat skor Gleason $\leq 7$ sejumlah 14 sampel dan adenokarsinoma prostat skor Gleason $>7$ sejumlah 16 sampel. Pembagian kelompok subyek penelitian ini dengan cut point skor Gleason 7 sesuai dengan rekomendasi Gleason ${ }^{12}$ yang menyatakan bahwa penelitian dengan jumlah sampel sedikit dan bertujuan untuk membandingkan perbedaan paramater tertentu, maka sebaiknya sampel adenokarsinoma prostat dibagi menjadi 2 kelompok dengan cut point skor Gleason 7. Sampel penelitian dianalisis ekspresi ZnT-1 dengan pulasan imunohistokimia. Data ekspresi ZIP-1 dan Caspase-3 merupakan data sekunder dari pulasan imunohistokimia ZIP-1 pada penelitian Septiawan et $a /^{9}$.

Protokol pulasan imunohistokimia yang digunakan dalam penelitian ini adalah protokol streptavidin-biotin berasal dari Star Trek detection kit sesuai dengan prosedur standar di Laboratorium Imunopatologi Departemen Patologi Anatomik FKUI. Pulasan imunohistokimia untuk menganalisis ekspresi ZnT-1 menggunakan antibodi primer polyclonal rabbit anti human ZnT-1 (Biorbyt, Cambridgeshire, UK) dengan pengenceran 1 : 800.

Ekspresi ZnT-1 dinyatakan positif (+), jika terpulas cokelat pada membran dan sitoplasma sel. Penilaian ekspresi ZnT-1 dilakukan pada 5 lapangan pandang, secara acak dan difoto menggunakan mikroskop cahaya Leica DM500 dengan kamera build in dengan perbesaran 400 kali. Penghitungan sel terpulas positif dilakukan dengan menggunakan software Image J secara semi- 
automated, seperti dapat dilihat pada gambar 1. Data diperoleh dengan menghitung persentase jumlah sel yang positif terhadap seluruh sel dari setiap lapang pandang.

Analisis data menggunakan software SPSS versi 17. Perbandingan profil ekspresi ZnT-1 menggunakan uji $\mathrm{T}$, jika data berdistribusi normal. Perbandingan profil ekspresi ZnT-1 menggunakan uji MannWhitney,jika data tidak berdistribusi normal. Uji korelasi ekspresi ZnT-1 dengan skor Gleason, serta korelasi ekspresi ZnT-1, ZIP-1 dan aktivasi Caspase-3 menggunakan uji korelasi Pearson jika data berdistribusi normal. Uji korelasi ekspresi ZnT-1 dengan skor Gleason, serta korelasi ekspresi ZnT-1, ZIP-1 dan aktivasi Caspase-3 menggunakan uji korelasi Spearman jika data tidak berdistribusi normal.

\section{HASIL DAN PEMBAHASAN}

Rerata persentase sel terpulas positif pada pulasan imunohistokimia yang merupakan ekspresi ZnT-1 dapat dilihat pada tabel 1.

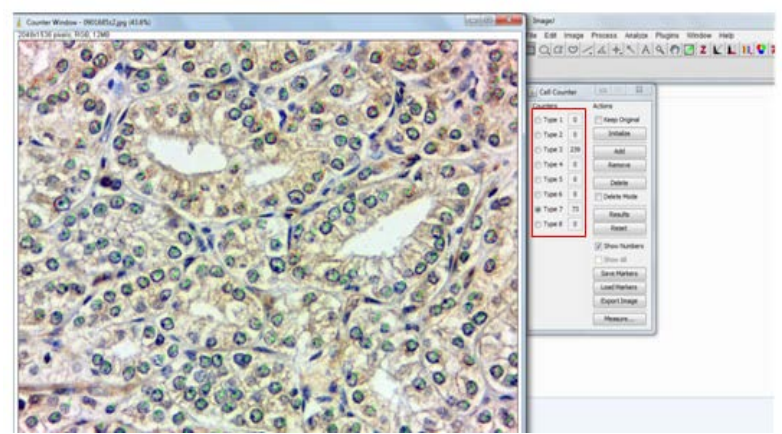

Gambar 1. Penghitungan sel terpulas positif dengan Image $\mathrm{J}$ secara semi automated.

Peneliti menghitung jumlah seluruh sel dengan langsung memberi tanda .3 (type 3) dan menghitung jumlah sel terpulas positif dengan langsung memberi tanda .7 (type 7) pada lapangan pandang tersebut. Software Image J menampilkan jumlah seluruh sel (type 3) dan sel terpulas positif (type 7) yang sudah ditandai oleh peneliti. Tampilan jumlah Software Image J dapat dilihat pada bagian yang ditandai kotak merah.

Tabel 1. Ekspresi ZnT-1

\begin{tabular}{ccc}
\hline $\begin{array}{c}\text { Kelompok } \\
\text { Diagnosis }\end{array}$ & $\begin{array}{c}\text { Jumlah } \\
\text { Sampel }\end{array}$ & $\begin{array}{c}\text { Rerata } \\
\text { Ekspresi ZnT-1 } \\
\text { (persentase sel } \\
\text { positif) }\end{array}$ \\
\hline BPH & 1 & $60,6^{*}$ \\
Skor Gleason $\leq 7$ & 14 & 60,79 \\
Skor Gleason $>7$ & 16 & $34,63^{\star *}$ \\
\hline Rerata & & 47,29 \\
\hline
\end{tabular}

*BPH yang didapatkan 1 sampel saja, sehingga hanya sebagai pembanding.

**Berbeda bermakna dengan kelompok adenokarsinoma skor Gleason $\leq 7(p=0,001 \mathrm{Uji} \mathrm{T})$

Pada penelitian ini, didapatkan rata-rata ekspresi ZnT-1 pada adenokarsinoma prostat skor Gleason $\leq 7$ lebih tinggi dibandingkan rata-rata ekspresi ZnT-1 pada adenokarsinoma prostat skor Gleason $>7 \quad(p=0,001)$. Ekspresi ZnT-1 berkorelasi dengan skor Gleason adenokarsinoma prostat $(r=-0,63$ dan $p=0,00)$. Makna hasil uji korelasi tersebut adalah penurunan ekspresi ZnT-1 berpengaruh pada peningkatan skor Gleason adenokarsinoma prostat.

Peningkatan ekspresi ZnT-1 berpengaruh pada penurunan skor Gleason adenokarsinoma prostat. Pulasan imunohistokimia ZnT-1 pada masingmasing kelompok diagnosis dapat dilihat pada gambar 2. Analisis statistik uji korelasi ekspresi ZnT-1, ZIP-1 dan aktivasi Caspase-3 pada adenokarsinoma prostat menggunakan uji korelasi Spearman, karena data ZIP-1 tidak berdistribusi normal. Hasil uji korelasi ekspresi ZnT-1, ZIP-1 dan aktivasi Caspase-3 pada adenokarsinoma prostat dapat dilihat pada tabel 2. 
Tabel 2. Korelasi ZIP-1, ZnT-1 dan Caspase-3 pada adenokarsinoma prostat

\begin{tabular}{ccccccc} 
& \multicolumn{2}{c}{ ZnT-1 } & \multicolumn{2}{c}{ ZIP-1 } & \multicolumn{2}{c}{ Caspase-3 } \\
\cline { 2 - 7 } & $\mathbf{R}$ & $\mathbf{P}$ & $\mathbf{R}$ & $\mathbf{p}$ & $\mathbf{r}$ & $\mathbf{p}$ \\
\cline { 2 - 7 } ZnT-1 & - & - & 0,1 & 0,3 & 0,1 & 0,4 \\
ZIP-1 & 0,1 & 0,3 & - & - & 0,4 & $0,03^{*}$ \\
Caspase- \\
3
\end{tabular}

Penelitian ini mendapatkan ekspresi ZIP-1 berkorelasi bermakna dengan aktivasi Caspase-3 ( $r=0,40$ dan $p=0,03$ ). Makna hasil uji korelasi tersebut adalah peningkatan ekspresi ZIP-1 berpengaruh pada peningkatan aktivasi Caspase-3, sedangkan penurunan ekspresi ZIP-1 berpengaruh pada penurunan aktivasi Caspase-3.

Uji korelasi lebih lanjut antara ekspresi ZIP-1, ZnT-1 dan aktivasi Caspase-3 dilakukan pada masing-masing kelompok adenokarsinoma prostat skor Gleason $\leq 7$ dan skor Gleason >7. Data ekspresi ZIP-1, ZnT-1 dan caspase-3 pada adenokarsinoma prostat skor Gleason $\leq 7$ berdistribusi normal, sehingga uji korelasi menggunakan uji korelasi Pearson. Ekspresi ZIP-1 berkorelasi bermakna dengan aktivasi Caspase-3 pada adenokarsinoma prostat skor Gleason $\leq 7(r=0,49$ dan $p=0,04)$. Hasil uji korelasi pada kelompok adenokarsinoma prostat skor Gleson $\leq 7$ dapat dilihat pada tabel 3.

Tabel 3. Korelasi ZIP-1, ZnT-1 dan Caspase-3 pada Adenokarsinoma Prostat skor Gleason $\leq 7$

\begin{tabular}{ccccccc}
\hline & \multicolumn{2}{c}{ ZnT-1 } & \multicolumn{2}{c}{ ZIP-1 } & \multicolumn{2}{c}{ Caspase-3 } \\
\cline { 2 - 7 } & $\mathbf{r}$ & $\mathbf{P}$ & $\mathbf{R}$ & $\mathbf{p}$ & $\mathbf{r}$ & $\mathbf{p}$ \\
\cline { 2 - 7 } ZnT-1 & - & - & 0,2 & 0,1 & 0,1 & 0,2 \\
ZIP-1 & 0,2 & 0,1 & - & - & 0,4 & $*$ \\
Caspas \\
e-3 & 0,1 & 0,2 & 0,4 & $0,04^{*}$ & - & - \\
\hline *Korelasi bermakna, $\mathrm{p}<0,05$ & & &
\end{tabular}

Ekspresi ZnT-1 berkorelasi bermakna dengan ekspresi ZIP-1 ( $r=0,5$ dan $p=0,04)$ pada adenokarsinoma prostat skor Gleason >7. Ekspresi ZIP-1 berpengaruh pada peningkatan ekspresi ZnT-1, sedangkan penurunan ekspresi ZIP-1 berpengaruh pada penurunan ekspresi ZnT-1.

Uji korelasi ZnT-1, ZIP-1 dan Caspase-3 dilakukan pada masing- masing skor Gleason adenokarsinoma prostat untuk melihat kemungkinan adanya perbedaan korelasi. Hasil uji korelasi pada masing-masing skor Gleason dapat dilihat pada tabel 4.

Tabel 4. Korelasi ZnT-1, ZIP-1 dan Caspase-3 pada setiap skor Gleason

\begin{tabular}{|c|c|c|c|c|c|c|c|}
\hline \multirow[t]{2}{*}{$\begin{array}{c}\text { Sko } \\
r \\
\text { Gle } \\
\text { aso } \\
n\end{array}$} & \multirow{2}{*}{$\begin{array}{c}\mathrm{Ju} \\
\mathrm{mla} \\
\mathrm{h} \\
\mathrm{Sa} \\
\mathrm{mp} \\
\mathrm{el}\end{array}$} & \multicolumn{2}{|c|}{$\begin{array}{l}\text { ZnT-1 dan } \\
\text { Caspase-3 }\end{array}$} & \multicolumn{2}{|c|}{$\begin{array}{l}\text { ZnT-1 dan } \\
\text { ZIP-1 }\end{array}$} & \multicolumn{2}{|c|}{$\begin{array}{c}\text { ZIP-1 } \\
\text { dan } \\
\text { Caspase } \\
-3\end{array}$} \\
\hline & & $r$ & $p$ & $r$ & $P$ & $\mathrm{R}$ & $p$ \\
\hline 6 & 4 & 0,68 & $\begin{array}{c}0,3 \\
2\end{array}$ & 0,72 & 0,27 & $\begin{array}{c}0,8 \\
9\end{array}$ & $\begin{array}{l}0, \\
1\end{array}$ \\
\hline 7 & 9 & $0,-$ & $\begin{array}{c}0,5 \\
9\end{array}$ & $\overline{0},-$ & 0,64 & $\begin{array}{c}0,2 \\
9\end{array}$ & $\begin{array}{l}0, \\
46\end{array}$ \\
\hline 8 & 3 & 0,7 & $\begin{array}{c}0,2 \\
5\end{array}$ & 0,76 & 0,23 & $\begin{array}{c}0,9 \\
9\end{array}$ & $\begin{array}{c}0, \\
02 \\
*\end{array}$ \\
\hline 9 & 9 & 0,31 & $\begin{array}{c}0,4 \\
1\end{array}$ & 0,11 & 0,77 & $\begin{array}{c}0,0 \\
6\end{array}$ & $\begin{array}{l}0 \\
87\end{array}$ \\
\hline 10 & 4 & 0,83 & $\begin{array}{c}0,1 \\
7\end{array}$ & 0,21 & 0,79 & $\begin{array}{c}0,3 \\
2\end{array}$ & $\begin{array}{l}0 \\
68\end{array}$ \\
\hline
\end{tabular}

Keseimbangan kadar $\mathrm{Zn}$ sangat diatur oleh transporter $\mathrm{Zn}$ yang terdapat pada sitoplasma dan membran sel. ${ }^{4}$ Tingkat ekspresi transporter $\mathrm{Zn}$ pada sel tumor berhubungan dengan tingkat keganasannya. ${ }^{4}$ Transporter Zn utama terdiri atas ZIP (SLC39) dan ZnT (SLC30). ${ }^{4} \mathrm{ZnT}$ berfungsi untuk mengeluarkan (efflux) Zn dari sel dan memasukkan $\mathrm{Zn}$ ke dalam organel intraseluler. ${ }^{4,5}$ Ekspresi ZnT-1 dipengaruhi oleh $\mathrm{Zn}$, karena $\mathrm{Zn}$ berikatan pada Metal Transcription Factor-1 (MTF-1) dan kemudian berikatan dengan Metal Response Element (MRE) pada promoter gen 

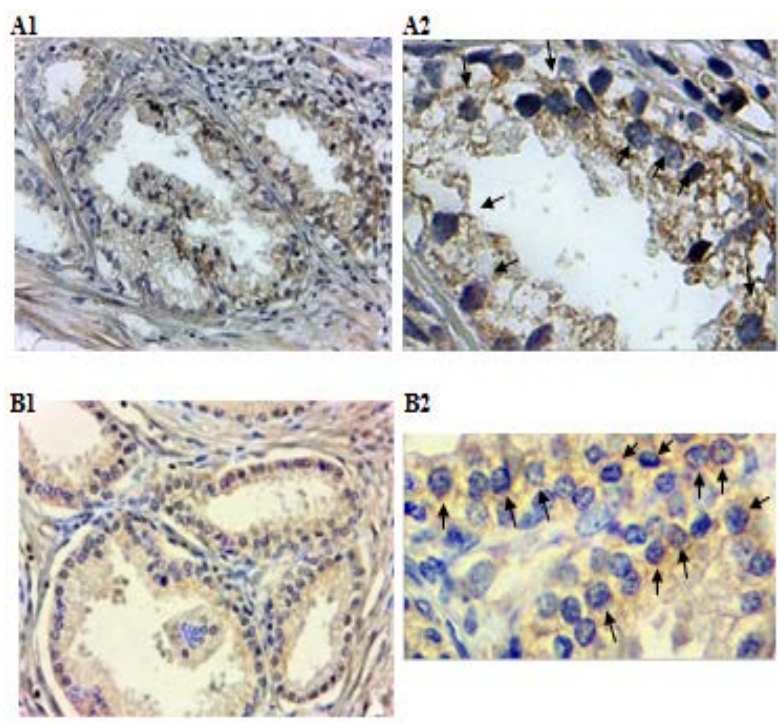

Cl

C2

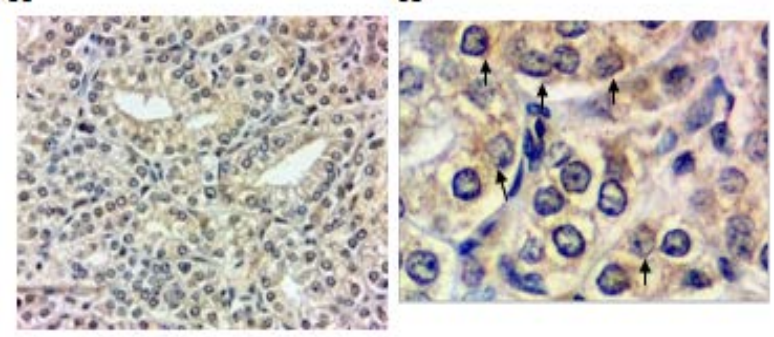

Gambar 2. Gambaran pulasan imunohistokimia ZnT-1. (A) 1. BPH perbesaran 400 kali 2. Perbesaran 1000 kali. (B) 1. Adenokarsinoma prostat skor Gleason $\leq 7$ perbesaran 400 kali. 2. Perbesaran 1000 kali. (C) 1. Adenokarsinoma prostat skor Gleason $>7$ perbesaran 400 kali. 2. Perbesaran 1000 kali. Tampak sel terpulas positif pada tanda panah.

ZnT-1 yang mengakibatkan terjadinya ekspresi gen $\mathrm{ZnT}-1 .{ }^{10,13}$

Sampel BPH pada penelitian ini hanya 1 sampel, sehingga ekspresi $\mathrm{ZnT}-1$ pada $\mathrm{BPH}$ tidak dapat dianalisis secara statistik kemaknaan perbedaannya dengan kelompok subyek penelitian, karena tidak dapat mewakili populasi dan belum ada standar ekspresi ZnT-1 pada BPH yang diakui secara umum. Ekspresi ZnT-1 pada jaringan $\mathrm{BPH}$ yang hanya 1 sampel pada penelitian ini adalah adalah 60,6 , sehingga hampir sama dengan ekspresi ZnT pada adenokarsinoma prostat skor Gleason $\leq 7$. Kondisi tersebut sejalan dengan hasil penelitian Beck et al dan Freeman et al (dikutip dari Franz et $a l^{4}$ ) yang tidak menemukan perubahan jumlah mRNA ZnT-1 pada kanker prostat dibandingkan dengan $\mathrm{BPH}$.

Hasil penelitian ini berbeda dengan penelitian Hasumi et $a l^{10}$ yang menemukan terjadinya penurunan jumlah mRNA ZnT-1 pada jaringan kanker prostat dibandingkan dengan BPH. Hasumi et $a l^{10}$ tidak menentukan derajat skor Gleason kanker prostat yang diteliti. Selain itu, Beck et al (dikutip dari Franz et $a l^{4}$ ) dengan metode RT PCR menemukan ekspresi mRNA ZnT-1 menurun pada kanker prostat dibandingkan dengan prostat normal. Perubahan epigenetik masih dapat berpengaruh pada hasil penelitian Beck et al (dikutip dari Franz et $a l^{4}$ ) dan Hasumi et $a l^{10}$, jika ingin diperbandingkan dengan penelitian ini. Hal lain yang dapat difikirkan sebagai penyebab kesamaan ekspresi ZnT-1 pada BPH dan adenokarsinoma prostat skor Gleason $\leq 7$ pada penelitian ini adalah kadar $\mathrm{Zn}$ pada $\mathrm{BPH}$ yang dapat lebih tinggi, lebih rendah dan tidak terdeteksi, dibandingkan dengan prostat normal. ${ }^{14}$ Padahal, Zn merupakan faktor penting terjadinya ekspresi ZnT-1.

Penelitian ini dapat membuktikan perbedaan ZnT-1 secara bermakna pada kelompok jaringan kanker prostat dengan derajat skor Gleason berbeda. Bukti tersebut yaitu ekspresi ZnT-1 pada adenokarsinoma prostat skor Gleason $\leq 7$ lebih tinggi dibandingkan dengan ekspresi ZnT-1 pada adenokarsinoma prostat skor Gleason $>7$ $(p<0,05)$. Penelitian ini mendapatkan pula ekspresi ZnT-1 berkorelasi dengan skor Gleason ( $r=-0,63$ dan $p=0,00)$. Makna hasil uji korelasi tersebut adalah penurunan ekspresi ZnT-1 berpengaruh pada 
peningkatan skor Gleason adenokarsinoma prostat, sedangkan peningkatan ekspresi ZnT-1 berpengaruh pada penurunan skor Gleason adenokarsinoma prostat.

Hasil penelitian ini yang mendapatkan korelasi ekspresi ZnT-1 dan skor Gleason sejalan dengan pernyataan Chasapis et $a 1^{15}$ tentang tingkat ekspresi transporter $\mathrm{Zn}$ pada sel tumor berhubungan dengan tingkat keganasannya. Hasil penelitian ini sejalan pula dengan Franz et $a l^{4}$ yang menyatakan bahwa penurunan kadar Zn pada prostat berkorelasi dengan peningkatan skor Gleason. Korelasi itu dapat terjadi, karena penurunan kadar $\mathrm{Zn}$ pada adenokarsinoma prostat menyebabkan penurunan ekspresi ZnT-1.

Peran Zn lainnya pada karsinogenesis kanker prostat adalah pada proses apoptosis melalui reaksi berantai pengaktifan caspase. Zn menyebabkan terbentuknya Bax associated pore formation pada membran luar mitokondria sebagai tempat terlepasnya Cytochrome C yang merupakan pencetus reaksi berantai pengaktifan Caspase. ${ }^{4,16}$ Caspase-3 yang aktif merupakan eksekutor utama terjadinya apoptosis yang menyebabkan fragmentasi DNA dan perubahan morfologi sel yang akan mengalami apoptosis. ${ }^{7}$ Ananthanarayanan et $a l^{17}$ membuktikan terjadinya penurunan ekspresi Caspase-3 pada jaringan adenokarsinoma prostat, dibandingkan dengan prostat normal. Penelitian Kosova et $a l^{18}$ menunjukkan pula berkurangnya Caspase-3 pada adenokarsinoma prostat dibandingkan dengan $\mathrm{BPH}$.

Penurunan kadar Zn pada prostat berkorelasi dengan peningkatan derajat skor Gleason adenokarsinoma prostat yang berkaitan dengan tingginya agresivitas. ${ }^{4}$
Kadar Zn yang rendah pada prostat menyebabkan terganggunya proses apoptosis yang terbukti dengan penurunan Caspase-3. Kadar Zn juga dipengaruhi oleh ZIP dan ZnT. Oleh karena itu, perlu untuk diketahui bagaimana korelasi ekspresi ZIP-1, ZnT-1 dan aktivasi Caspase-3 dalam karsinogenesis prostat.

Uji korelasi menunjukkan ekspresi ZIP1 berkorelasi secara bermakna dengan aktivasi Caspase-3 ( $r=0,40$ dan $p=0,03$ ) pada adenokarsinoma prostat. $\mathrm{Uji}$ korelasi penelitian ini pada adenokarsinoma prostat $\leq 7$ mendapatkan ekspresi ZIP-1 berkorelasi dengan aktivasi Caspase-3 $\quad(r=0,49$ dan $p=0,04)$. Uji korelasi setiap skor Gleason pada penelitian ini juga menunjukkan ekspresi ZIP-1 berkorelasi kuat dengan aktivasi Caspase-3 pada adenokarsinoma prostat skor Gleason 8 ( $r=0,99$ dan $p=0,02)$. Pada penelitian sebelumnya yang dilakukan Septiawan et $a{ }^{14}$, ditemukan ekspresi ZIP-1 yang berkorelasi kuat secara bermakna dengan aktivasi Caspase-3 pada adenokarsinoma prostat skor Gleason <8 $(r=0,7-0,9$ dan $p<0,05)$. Fakta-fakta tersebut menunjukkan ZIP-1 lebih berpengaruh pada apoptosis prostat, dibandingkan dengan pengaruh ZnT-1 pada apoptosis prostat. Hal ini mengindikasikan bahwa ZIP-1 lebih berpotensi untuk menjadi faktor prognosis dibandingkan dengan ZnT-1.

Pada uji korelasi ZIP-1, ZnT-1 dan Caspase-3 pada setiap skor Gleason menunjukkan ekspresi ZIP-1 berkorelasi kuat dengan aktivasi Caspase-3 pada adenokarsinoma prostat skor Gleason 8 $(r=0,99$ dan $p=0,02)$. Korelasi menjadi tidak bermakna pada adenokarsinoma prostat skor Gleason 9 dan 10. Hal tersebut dapat terjadi, karena adanya faktor lain yang 
mempengaruhi ZIP-1 dalam homeostasis Zn terkait dengan apoptosis. Penelitian Mihelich et $a{ }^{19}$ menunjukkan ekspresi miR (microRNA)-183, miR-96 dan miR-182 lebih tinggi pada jaringan adenokarsinoma prostat, dibandingkan dengan jaringan prostat normal dan ZIP-1 berkorelasi kuat $(r=-0,77$ dan $p=0,009)$ dengan miR-182. Mihelich et $a l^{19}$ juga mendapatkan transfeksi miR-183, miR-96 dan miR-182 pada galur sel prostat normal menyebabkan penurunan mRNA dan protein ZIP-1, serta mRNA ZnT-1. Selain itu, transfeksi miR-183, miR-96 dan miR-182 pada galur sel prostat normal menyebabkan penurunan kadar $\mathrm{Zn} .{ }^{19}$

Hasil penting lain dari penelitian ini adalah ZnT-1 berkorelasi bermakna dengan ZIP-1 ( $r=0,51$ dan $p=0,04)$ pada adenokarsinoma prostat skor Gleason $>7$. Fakta ini menunjukkan potensi $\mathrm{Zn}$ dan transporter $\mathrm{Zn}$ menjadi dasar terapi pada adenokarsinoma prostat derajat tinggi, karena tidak terjadinya penyimpangan korelasi transporter $\mathrm{Zn}$ pada adenokarsinoma derajat tinggi, sedangkan pada terapi anti androgen menjadi tidak efektif akibat penyimpangan AR yang masih dapat aktif tanpa adanya androgen (androgen independent). Asumsi tersebut diperkuat oleh penelitian $Y a n$ et $a l^{20}$ yang menunjukkan pemberian $\mathrm{Zn}$ tetap menyebabkan peningkatan apoptosis pada galur sel adenokarsinoma prostat PC-3 yang androgen independent.

Hasil penelitian ini yang memperjelas peranan transporter $\mathrm{Zn}$ sebagai faktor prognosis adenokarsinoma prostat, harus diperkuat oleh penelitian selanjutnya, karena homeostasis Zn pada prostat juga dipengaruhi oleh Metallothionein dan ZIP-4. Metallothionein merupakan protein pengikat $\mathrm{Zn}$, berperan sebagai pemberi (donor) Zn untuk proses intraseluler dan sebagian besar $\mathrm{Zn}$ di dalam sitoplasma terikat pada Metallothionein. ${ }^{21-23}$ Fungsi Metallothionein sebagai gudang $\mathrm{Zn}$ di dalam sel ini menyebabkan Metallothionein berperan penting dalam homeostasis $\mathrm{Zn}$ pada prostat. Selain itu, pola ekspresi Metallothionein sama dengan pola ekspresi ZnT-1 dan protein proapoptosis Bax, yaitu dipengaruhi oleh Zn yang terikat pada MTF-1 dan kemudian berikatan dengan MRE pada promoter gen yang bersangkutan. ${ }^{21-23}$ Oleh karena itu, korelasi Metallothionein, ZnT-1 dan apoptosis berkemungkinan besar dapat terjadi.

ZIP-4 yang berfungsi sama dengan ZIP-1 sebagai $Z n$ importer ke dalam sel prostat, juga dapat berpengaruh pada kadar $\mathrm{Zn}$ prostat. Penelitian Chen et $\left.a\right|^{24}$ menemukan penurunan ZIP-4 pada adenokarsinoma prostat yang dibandingkan dengan BPH. Bahkan, ketika dilakukan silencing terhadap gen ZIP-4, Chen et $\left.a\right|^{24}$ mendapatkan peningkatan proliferasi dan invasi sel tumor prostat. Korelasi antara ZIP1, ZIP-4, Metallothionein, ZnT-1, miR-183, miR-96, miR-182 dan Caspase-3 pada jaringan-jaringan prostat dengan tingkat keganasan berbeda perlu untuk dipelajari pada penelitian selanjutnya, agar mekanisme homeostasis $\mathrm{Zn}$ pada karsinogenesis prostat dapat semakin jelas. Kejelasan ini penting untuk lebih memastikan peran transporter Zn sebagai faktor prognosis adenokarsinoma prostat.

\section{SIMPULAN}

Dari penelitian ini dapat disimpulkan bahwa Ekspresi ZnT-1 berkorelasi dengan skor Gleason. Ekspresi ZnT-1 pada skor 
Gleason $>7$ lebih rendah dibandingkan pada skor Gleason $\leq 7$ (34,63 vs 60,$79 ; p<0,05)$. Ekspresi ZnT-1 berkorelasi dengan ekspresi ZIP-1 pada skor Gleason >7. Ekspresi ZIP-1 berkorelasi dengan aktivasi Caspase-3 pada skor Gleason $\leq 7$.

\section{DAFTAR RUJUKAN}

1. Globocan.larc.Fr [internet]. International Agency for Research on Cancer. GLOBOCAN 2008: Estimated cancer incidence, mortality and prevalence worldwide in 2012. [cited 2012 Dec 3]. Avaible from http://globocan.iarc.fr/Pages/fact sheets po pulation.aspx

2. Globocan.larc.Fr [internet]. International Agency for Research on Cancer. GLOBOCAN 2012: Estimated cancer incidence, mortality and prevalence worldwide in 2012. [cited 2014 Jan 17].Avaible from http://globocan.iarc.fr/Pages/fact sheets po pulation.aspx

3. Kumar, Abbas, Fausto, Aster. Robbins and cotran pathologic basis of disease. $8^{\text {th }}$ ed. Philadelphia: Saunders; 2010.

4. Franz MC, Anderle $P$, Burzle $M$. Zinc transporters in prostate cancer. Mol Aspects Med. 2013;34:735-41.

5. Palmiter RD, Huang L. Efflux and compartmentalization of zinc by members of the SLC30 family of solute carriers. Eur J Physiol. 2004;447:744-51.

6. Costello LC, Franklin RB. The clinical relevance of the metabolism of prostate cancer; zinc and tumor suppression: connecting the dots. Mol Cancer. 2006;55:17

7. Pizem J, Cor A. Detection of apoptotic cells in tumour paraffin sections. Radiol Oncol. 2003;37:225-32.

8. Santamaria L, Martin R, Gomez V. Stereologic estimation of $\mathrm{KI}-67$, caspase 3 , and GSTP1 positive cells in prostate lesions. Image Anal Stereol. 2005;24:77-84.

9. Septiawan DA. Analisis ekspresi protein ZIP1 dan Caspase-3 pada adenokarsinoma prostat (Tesis). 2013.

10. Hasumi M, Suzuki K, Matsui H. Regulation of metallothionein and zinc transporter expression in human prostate cancer cells
Ekspresi ZIP-1 berkorelasi kuat dengan aktivasi Caspase-3 pada skor Gleason 8. Nilai ekspresi Transporter Zn (ZnT-1 dan ZIP1) yang rendah berpotensi untuk menjadi faktor prognosis adenokarsinoma prostat.

and tissues. Cancer Letters. 2003;200:18795.

11. Winter RN, Kramer A, Borkowski A. Loss of caspase-1 and caspase- 3 protein expression in human prostate cancer. Cancer Res. 2001;61:1227-32.

12. Da Motta VP, Malafaia O, Ribas-Filho JM. Caspase-3 and CD-34 expression in prostate adenocarcinoma. Rev Col Bras Cir. 2009;36:223-9.

13. Langmade SJ, Ravindra R, Daniels PJ. The transcription factor MTF-1 mediates metal regulations of the mouse $\mathrm{ZnT1}$ gene. J Biol Chem. 2000;275:34803-9.

14. Cortesi M, Fridman E, Volkov A, Shilstein S, Chechik R. New prospective for noninvasive detection, grading, size evaluation, and tumor location of prostate cancer. Prostate. 2010;70(15):1701-8.

15. Chasapis CT, Loutsidou AC, Spiliopoulou, Stefanidou ME. Zinc and human health: an update. Arch Toxicol. 2012;86:521-34.

16. Costello LC, Franklin RB. The important role of the apoptotic effects of zinc in the development of cancers. J Cell Biochem. 2009;106(5):750-57.

17. Ananthanarayanan V, Deaton RJ, Yang XJ, Pins MR, Gann PH. Alteration of proliferation and apoptotic markers in normal and premalignant tissue associated with prostate cancer. BMC Cancer. 2006;6(73).

18. Kosova F, Temeltas G, Ari Z, Lekili M. Possible relations between oxidative damage and apoptosis in benign prostate hyperplasia and prostate cancer patiens. Tumor Biol. 2014;35:4259-99.

19. Mihelich LB, Khramtsova EA, Arva N, Vaishnav A, Johnson DN. miR-183-96-182 cluster is overexpressed in prostate tissue and regulates zinc homeostasis in prostate cells. J Biol Chem. 2011;286:44503-11 
20. Yan M, Hardin K, Ho E. Differential response to zinc-induced apoptosis in benign prostate hyperplasia and prostate cancer cells. Nutr Biochem. 2010;21:687-94.

21. Hlavna $M$, Raudenske $M$, Hudcova $K$, Gumulec J, Sztalmachova M. MicroRNAs and zinc metabolism-related gene expression in prostate cancer lines treated with zinc(II) ions. Int Jour Onc. 2012;41:2237-44.
22. Tapiero H, Tew KD. Trace elements in human physiology and pathology: zinc and metallothioneins. Biomed Pharmacother. 2003;57:399-411.

23. Cousines RJ, Liuzzi JP, Lichten LA. Mammalian zinc transport, trafficking and signals. J Bio Chem. 2006;281:24085-889.

24. Chen $Q$, Zhang $Z$, Yang $Q$, Shan $G$. The role of zinc transporter ZIP4 in prostate carcinoma. Urol Oncol. 2012;30:906-11. 